\title{
Evidence of Soil Health Benefits of Flooded Rice Compared to Fallow Practice
}

\author{
Jehangir Bhadha ${ }^{1,2}$, Raju Khatiwada ${ }^{1}$, Salvador Galindo ${ }^{1}, \mathrm{Nan}_{\mathrm{Xu}^{1,2}}$ \& Jay Capasso ${ }^{1,2}$ \\ ${ }^{1}$ Everglades Research and Education Center, University of Florida, USA \\ ${ }^{2}$ Soil and Water Sciences Department, University of Florida, USA \\ Correspondence: Jehangir Bhadha, Everglades Research and Education Center, Soil and Water Sciences \\ Department, University of Florida, USA. E-mail: jango@ufl.edu
}

Received: June 30, 2018 Accepted: July 20, 2018 Online Published: August 2, 2018

doi:10.5539/sar.v7n4p31 URL: https://doi.org/10.5539/sar.v7n4p31

\begin{abstract}
Flooded rice (Oryza sativa L.) in south Florida is grown commercially in rotation with sugarcane and vegetables. From 2008 to 2018, rice production has doubled. During the spring-summer, nearly $200 \mathrm{~km}^{2}$ of fallow sugarcane land is available for rice production. In 2017, approximately $113 \mathrm{~km}^{2}$ of rice were planted in the region. The net value of growing rice as a rotation crop far exceeds its monetary return. This study evaluated soil health parameters before and after rice cultivation and compared them against two other common summer farming practices - fallow fields and flooded-fallow. The soil health parameters that were tested as part of this study included soil $\mathrm{pH}$, bulk density, water holding capacity, cation exchange capacity, organic matter, active carbon and nutrient content. Results indicated an increase in soil $\mathrm{pH}$, and a significant reduction in soil bulk density due to rice cultivation. Water holding capacity increased significantly under all flooded land use practices compared to fallow fields. Cation exchange capacity significantly increased when sugarcane fields were cultivated with rice and ratoon rice, nearly doubled from 58 to $101 \mathrm{cmolc} \mathrm{kg}^{-1}$. Small, yet significant $3 \%$ increase in organic matter was observed when sugarcane fields were cultivated with ratoon rice. Almost $16 \mathrm{~g} \mathrm{~kg}^{-1}$ of active $\mathrm{C}$ is being generated within fallow soils, whereas less than half that under flooded practices, limiting the amount of soil loss via oxidation. Based on the soil health index, rice cultivation and flooded-fallow improved overall soil quality compared to fallow lands.
\end{abstract}

Keywords: flooded-fallow, rice cultivation, histosols, soil health, active carbon

\section{Introduction}

\subsection{Rational \& Justification}

Soil health is a term synonymous with soil quality. It refers to the chemical, biological, and physical characteristics of a soil that influences its ability to function sustainably, and to satisfy the needs of humans, support plants, and cycle elements, water, and energy between Earth systems (Doran et al., 1994). It is often said that a handful of productive soil contains more living organisms than people living on Earth. Managing soil health involves maintaining a habitat for these living organisms, which include bacteria, algae, fungi, and plants (Alkorta et al., 2003). When these soil organisms die and decay, organic matter is created, which is primarily made up of carbon compounds. Organic matter is a key component of soil health because it fuels the diverse biological functions of soil organisms, which obtain their energy and nutrients by breaking down plant residues (Follett et al., 1987). Organic matter improves soil structure, reduces compaction, and minimizes soil erosion by enhancing macropore stability and water infiltration. Enhanced soil structure also improves the ability of agricultural fields to withstand conditions of drought or extreme rainfall. Such hydrology considerations are particularly relevant to the health of Florida soils because potential drainage and surface runoff issues are widespread. Mineralization of organic matter helps supply crops with essential nutrients, including nitrogen (N), phosphorus $(\mathrm{P})$, potassium $(\mathrm{K})$, and most of the micronutrients. Therefore, agronomic practices should consider these various biological, physical, and chemical characteristics of soil health and the integrated role soil organic matter plays in supporting agricultural systems.

\subsection{Study Area}

The Everglades Agricultural Area (EAA) consists of a portion of the original Everglades region of south Florida, 
USA, which was artificially drained in the mid-twentieth century to sustain a farming industry within the region. Nearly $80 \%$ of the $1,800 \mathrm{~km}^{2}$ of farming land is used to grow sugarcane while the remaining $20 \%$ is used in rotation to grow winter vegetables and rice. Soil loss due to oxidation is a major concern for growers in the region. The organic soils formed over a period of thousands of years as a result of organic matter accretion within the flooded sawgrass prairies south of Lake Okeechobee. Beginning early 1900s, soils within the EAA were drained for crop production. Gradually, organic matter decomposition exceeded accretion, resulting in loss of soil and lowering of the surface elevation, a process referred to as "subsidence". Underneath these organic soils is hard limestone bedrock, and this makes subsidence all the more important since land cultivation and water management would be difficult. It is apparent that soil loss due to subsidence is not constant, and in fact has decreased by nearly 50\% between 1924-1967 to 1968-2009 (Wright \& Snyder, 2009). A major factor influencing the decline in soil subsidence has been improved water management throughout the EAA. Studies have shown that soil loss due to oxidation is directly related to the redox condition of the soil (Ponnamperuma, 1984; Reddy \& Patrick, 1975). Generally, well drained soils oxidize at a faster rate than under flooded or poorly drained conditions. Implementation of Best Management Practices (BMPs) in the mid-1990s has led to more water storage on EAA fields, which helps to reduce organic matter decomposition and decrease soil oxidation rate (Bhadha \& Schroeder, 2017). Another commonly implemented BMP in the EAA is to rotate sugarcane with rice. Since rice in the EAA is typically grown under flooded conditions, it is an optimal rotational crop planted in late spring-early summer which helps reduce soil oxidation by field flooding. Continuation of BMP implementation by growers, development of flood-tolerant crop cultivars, reduced tillage, and adoption of crop rotations, has the potential for minimizing subsidence and increase the longevity for agricultural use. Soil-forming factors are well known and soil properties are measurable, but the current emphasis on soil health requires an integrative assessment of how intrinsic soil properties are affected by soil management. Evaluating changes in soil properties associated with flooded rice fields during the summer months in the EAA provides us an opportunity to assess the effect of soil management associated with flooding versus fallow.

\subsection{Rice Cultivation in South Florida}

Rice has been commercially grown in the EAA since 1977 after it was demonstrated that rice could be successfully grown in rotation with sugarcane during the summer fallow period (Alvarez et al., 1979). The EAA comprises $1,800 \mathrm{~km}^{2}$ of Histosols that are devoted to sugarcane production. During the summer period, more than $200 \mathrm{~km}^{2}$ of fallow sugarcane land is available for rice production. In 2017, approximately $113 \mathrm{~km}^{2}$ of rice were planted in the EAA (FRG, 2017). The net value of growing rice in the EAA as a rotation crop far exceeds its monetary return. In addition to being a food crop in Florida, production of flooded rice provides several benefits to the agroecosystem. By flooding fields, growers greatly reduce the negative impacts from issues related to soil subsidence (Wright \& Snyder, 2009), nutrient depletion, and insect pests (Cherry et al., 2015). This, in turn, enhances the subsequent sugarcane crop and maximizes the longevity of the soil by reducing soil loss due to oxidation. In addition, incorporating rice as a rotation crop in the EAA during the summer months also provides local employment (Schueneman et al., 2008).

\subsection{Objectives}

The objectives of this study were to (i) evaluate soil health response of cultivating flooded rice in South Florida compared to alternative practices such as flooded fallow and fallow; (ii) develop a soil health index that will rank land use practices based on its impact on soil quality. Six different farming practices were evaluated for a suit of soil health indicators. The six farming practices included sugarcane followed by ratoon rice (two successive rice crops), sugarcane followed by single rice crop; sweetcorn followed by rice; lettuce followed by rice; sugarcane followed by flooded fallow; and sugarcane followed by fallow. The six farming practices are shown in Figure 1. These farming practices are typical of the EAA during the summer period. 


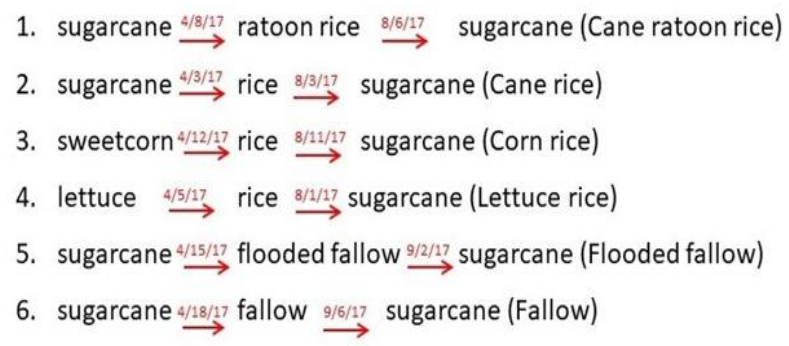

Figure 1. Six farming practices in the summer. The red arrows indicate when soil samples were collected

\section{Material and Methods}

\subsection{Soil Health Indicators}

Six $0.16 \mathrm{~km}^{2}$ commercial fields were selected for each farming practice, and a composite soil sample was collected from the top $15 \mathrm{~cm}$ from each field. A composite sample comprised of mixing ten soil samples collected along a transect from individual fields. The soil samples from each field were collected twice, just before rice was planted (pre) and right after the rice was harvested (post), approximately $120 \mathrm{~d}$ apart. In the case of flooded fallow, the soil samples were collected just before the flooding was initiated and right after the water was drained, approximately $140 \mathrm{~d}$ apart. In case of the fallow fields, soil samples were collected just before the fields were left fallow and just before they were tilled to prepare fall planting, approximately $130 \mathrm{~d}$ apart. All soil samples were collected in 1-gallon Ziploc pouches and transported to the Soil, Water and Nutrient Management Laboratory at the Everglades Research and Education Center where they were analyzed for the various soil health indicators.

Pre and post soil samples were collected from each field were air dried, passed through $2 \mathrm{~mm}$ sieve and analyzed for various soil health parameters. Soil health indicators tested include $\mathrm{pH}$, bulk density (BD), organic matter content (OM), maximum water holding capacity (MWHC), cation exchange capacity (CEC), potassium permanganate oxidizable active carbon (Active C), Mehlich 3 phosphorus (M3P) and potassium (M3K), total phosphorus (TP) and total Kjeldahl nitrogen (TKN). pH was determined using 1:10 soil:water extract using Accumet AB250 pH meter. Bulk density was calculated measuring soil mass in the known core volume. Organic matter content was determined based on loss on ignition (LOI) at $550^{\circ} \mathrm{C}$. Maximum water holding capacity was determined using modified method described by Jenkinson and Powlson (1976) measuring amount of water retained in soil after saturation. Cation exchange capacity was estimated using the ammonium acetate method (Sumner and Miller, 1996) and ammonium concentrations were analyzed with flow injection analysis on a Lachat analyzer (QuikChem Method 10-107-06-2-A. Hach Company, Loveland, CO). The ammonium concentration in $\mathrm{mg} \mathrm{L}^{-1}$ was converted to its equivalent on cmolc $\mathrm{kg}^{-1}$ soil. Active $\mathrm{C}$ was determined based on potassium permanganate $\left(\mathrm{KMnO}_{4}\right)$ oxidizable carbon using $0.2 \mathrm{M} \mathrm{KMnO}_{4}$ for muck soils. Approximately $2 \mathrm{~g}$ of soil was reacted with $20 \mathrm{~mL}$ of $0.2 \mathrm{M} \mathrm{KMnO}_{4}$ for two minutes, filtered and supernatant solution was analyzed for remaining concentration of $\mathrm{KMnO}_{4}$ using Thermo Scientific Genesys 30 spectrophotometer at $550 \mathrm{~nm}$. Active C concentration was determined from the amount of $\mathrm{KMnO}_{4}$ oxidized. Extractable $\mathrm{P}$ and $\mathrm{K}$ were determined based on Mehlich-3 extraction technique analyzed using Agilent 5110 inductively coupled plasma-optical emission spectrometer (ICP-OES, Santa Clara CA). Total P was determined by ashing samples followed by extraction with $6 \mathrm{M} \mathrm{HCl}$ and analyzed using ICP-OES. Total Kjeldahl nitrogen was determined by digestion followed by colorimetric determination (EPA method 351.2). Statistical analysis was done using t-test for two sample replicates assuming unequal variances at $\alpha=0.05$ level of significance with Microsoft Excel.

\subsection{Soil Health Index}

Soil health index (SHI) was developed based on three step framework of (i) indicator selection, (ii) interpretation, and (iii) indexing based on Cornell Comprehensive Assessment of Soil Health Manual (Moebius-Clune et al., 2016) adapted from (Andrews et al., 2004). The indicators were used to develop scoring function between 0 to 100 by estimating the cumulative normal distribution (CND) function using the mean and standard deviation of soil samples collected from rice fields in the EAA. Details regarding the indexing and scoring is available at Cornell Comprehensive Assessment of Soil Health Manual (Moebius-Clune et al., 2016). Increase in value was given positive score and decrease in indicator value was given negative score for all parameters except $\mathrm{pH}, \mathrm{BD}$ and Active $\mathrm{C}$ as increase in these parameter value are non-desirable from sustainable agricultural perspective within the EAA (Table 1). Overall scores were calculated in two ways - first based on average of all the scores; 
and alternatively excluding nutrient scores (M3P, M3K, TKN and TP).

Table 1. Soil health scoring guide

\begin{tabular}{lcccccccccc}
\hline & $\mathrm{pH}$ & $\mathrm{BD}^{\dagger}$ & $\mathrm{OM}$ & MWHC & CEC & Active C & M3P & M3K & TKN & TP \\
\hline Increase & - & - & + & + & + & - & + & + & + & + \\
Decrease & + & + & - & - & - & + & - & - & - & - \\
\hline
\end{tabular}

$+=$ positive; $-=$ negative. $\uparrow \mathrm{BD}=$ bulk density; $\mathrm{OM}=$ organic matter content; $\mathrm{MWHC}=$ maximum water holding capacity; Active $\mathrm{C}=$ active carbon; $\mathrm{CEC}=$ cation exchange capacity; $\mathrm{M} 3 \mathrm{P}=$ Mehlich 3 phosphorus; $\mathrm{M} 3 \mathrm{~K}=$ Mehlich 3 potassium; $\mathrm{TP}=$ total phosphorus; $\mathrm{TKN}=$ total Kjeldahl nitrogen

\section{Results}

\subsection{Change in Soil Health Indicators}

The $\mathrm{pH}$ for all the soil samples were neutral to alkaline and ranged from 7.08 to 8.06. Pre and post sample $\mathrm{pH}$ remained similar for ratoon rice and corn rice; however, there was significant increase in soil $\mathrm{pH}$ for rest of the farming practices (Figure 2).

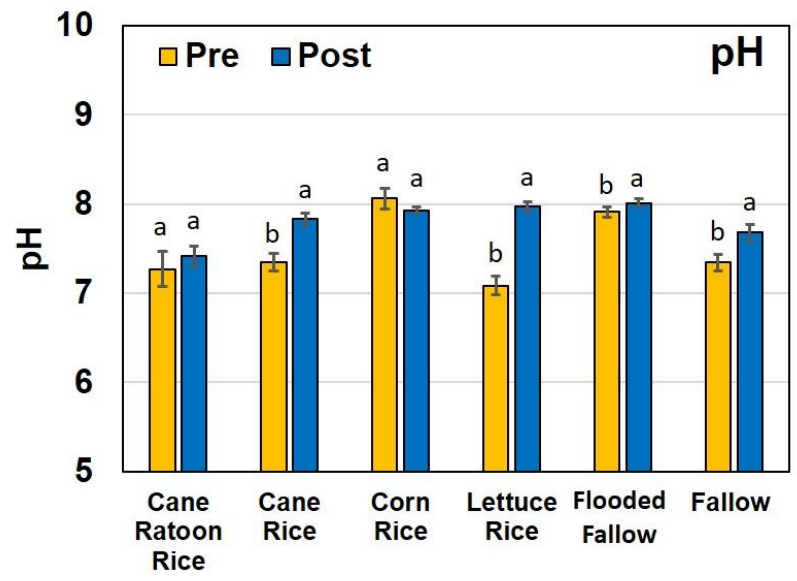

Figure 2. Changes in soil $\mathrm{pH}$ pre and post six farming practice (mean and standard deviation). Different lower case alphabets correspond to significant differences $(\mathrm{p} \leq 0.05)$

Bulk density of the soils ranged from 0.50 to $0.66 \mathrm{~g} \mathrm{~cm}^{-3}$ (Figure 3). While all farming practices that involved rice cultivation showed a slight decrease in $\mathrm{BD}$; there was a significant decrease in $\mathrm{BD}$ observed between pre and post soil of the Cane rice farming practice. There was also a significant increase in soil BD between pre and post farming practice of the flooded fallow fields.

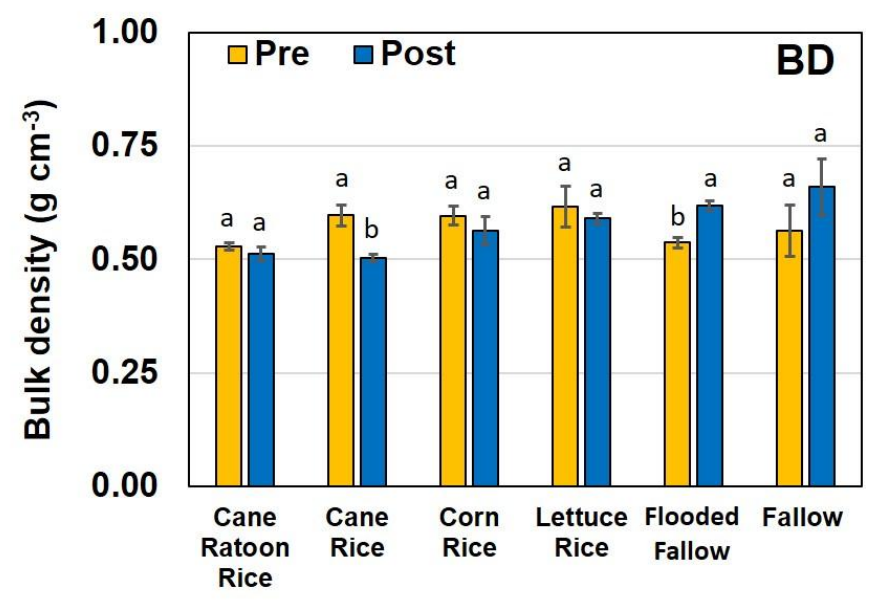

Figure 3. Changes in soil bulk density (BD) pre and post six farming practice (mean and standard deviation).

Different lower case alphabets correspond to significant differences $(\mathrm{p} \leq 0.05)$ 
Maximum water holding capacity of soils in Cane rice, Cane ratoon rice, Corn rice, Lettuce rice and Flooded fallow farming practices all showed significant increase between pre and post samples; while fallow treatment remained similar (Figure 4). The MWHC capacity of all post study samples were in range of 125 to $283 \%$.

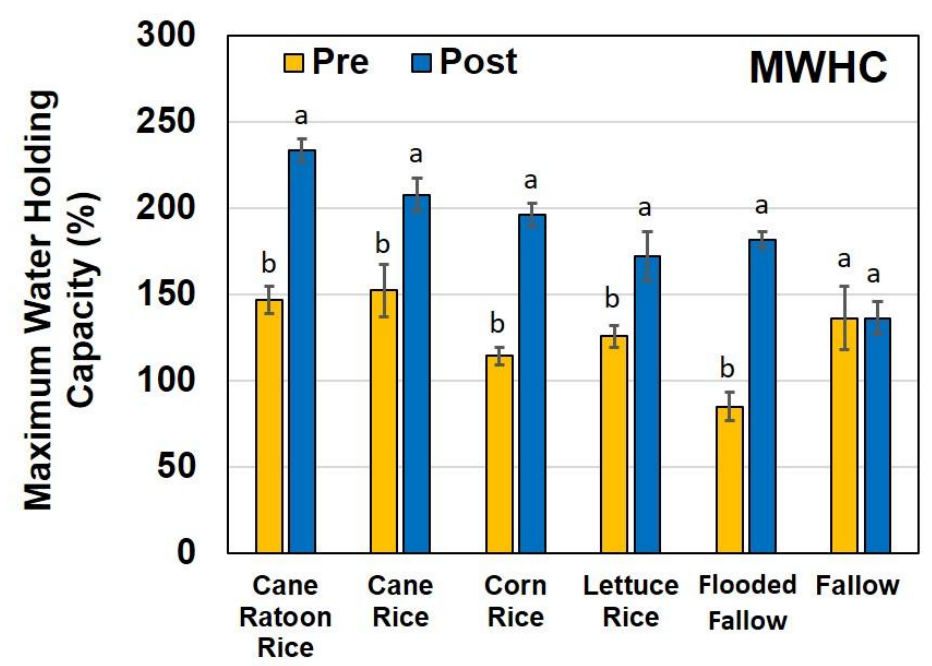

Figure 4. Changes in soil maximum water holding capacity (MWHC) pre and post six farming practice (mean and standard deviation). Different lower case alphabets correspond to significant differences $(\mathrm{p} \leq 0.05)$

Cation exchange capacity of soils collected pre farming practice ranged from 46 to $94 \mathrm{cmolc} \mathrm{kg}^{-1}$ and post farming soil samples were in the range of 73-101 cmolc kg-1 (Figure 5). Cation exchange capacity significantly increased for Cane ratoon rice and Cane rice treatments; whereas remained statistically similar for Corn rice, Flooded fallow and Fallow treatments.

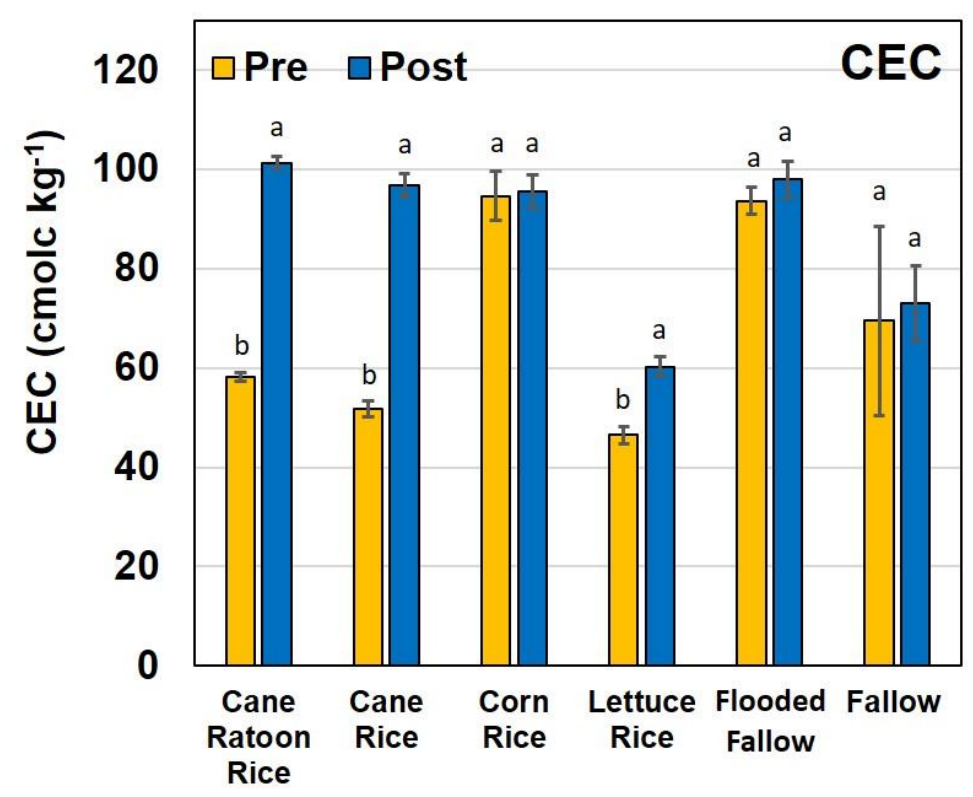

Figure 5. Changes in soil cation exchange capacity (CEC) pre and post six farming practice (mean and standard deviation). Different lower case alphabets correspond to significant differences $(p \leq 0.05)$

Organic matter content of samples ranged from $72-83 \%$ except for fallow treatments which had $56-57 \%$ OM (Figure 6).There was significant increase of 3\% OM content for Cane ratoon rice, while other farming practices remained statistically similar and showed no change between pre and post soil samples. 


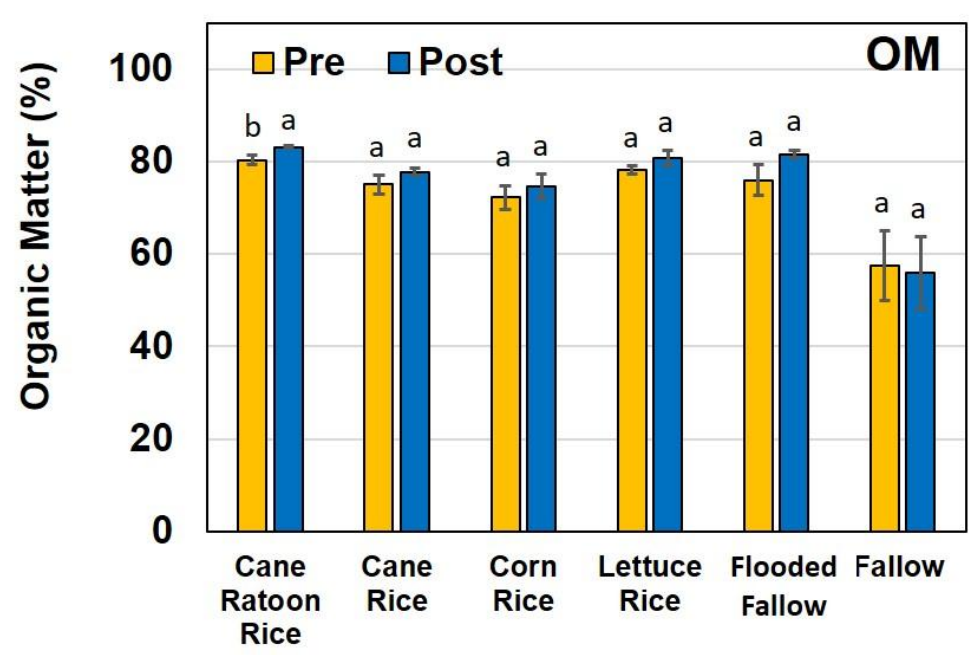

Figure 6. Changes in soil organic matter (OM) content pre and post six farming practice (mean and standard deviation). Different lower case alphabets correspond to significant differences $(\mathrm{p} \leq 0.05)$

There was significant increase observed in the soil active carbon content for Cane ratoon rice, Corn rice and Fallow treatments (Figure 7). Active $\mathrm{C}$ content decreased for Lettuce rice treatment; whereas it remained statistically similar for Cane rice and Flooded fallow treatments.

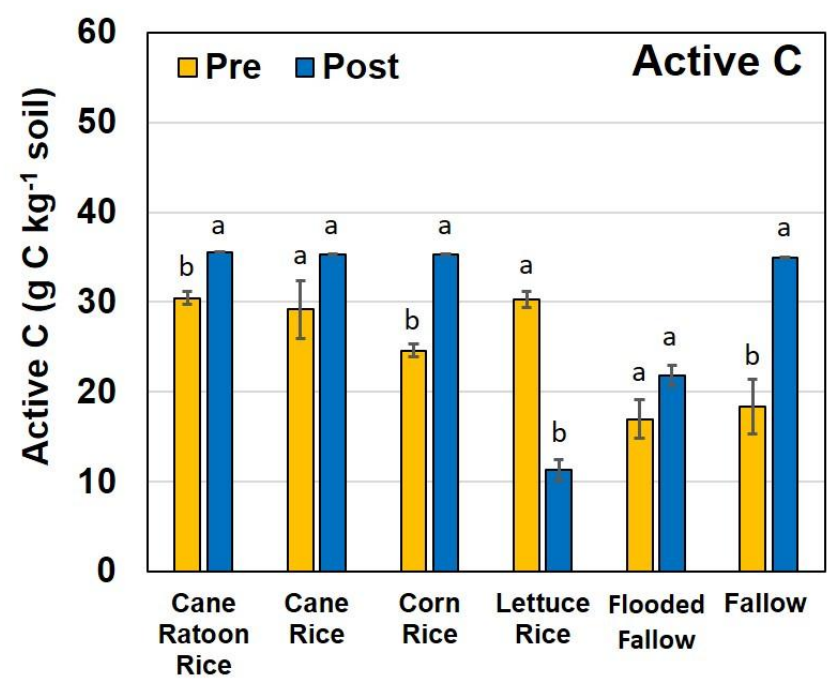

Figure 7. Changes in soil active carbon content pre and post six farming practice (mean and standard deviation). Different lower case alphabets correspond to significant differences $(\mathrm{p} \leq 0.05)$

Except for Lettuce rice and Flooded fallow treatments, there was no significant change in TP concentration for other treatments between pre and post soil (Figure 8). Mean TP concentrations reduced in Cane ratoon rice, Cane rice, and Lettuce rice between the pre and post soil, whereas it increased in Corn rice, Flooded fallow and in Fallow fields. Lettuce rice TP concentration decreased from 928 to $600 \mathrm{mg} \mathrm{kg}^{-1}$ whereas Flooded fallow TP increased from 950 to $3478 \mathrm{mg} \mathrm{kg}^{-1}$. Total Kjeldahl nitrogen concentration of soil samples ranged from 15000 $\mathrm{mg} \mathrm{kg}^{-1}$ to $21000 \mathrm{mg} \mathrm{kg}^{-1}$. Mean TKN concentrations reduced in all except the Fallow treatment between the pre and post soil. Total Kjeldahl nitrogen did not change significantly for Corn rice, Flooded fallow and Fallow treatments; whereas there was significant decrease for rest of the treatments. Mean M3P concentration between the pre and post soil was significantly reduced in Lettuce rice treatment. M3K concentration was in range of 148 to $722 \mathrm{mg} \mathrm{kg}^{-1}$ for pre samples and 102 to $278 \mathrm{mg} \mathrm{kg}^{-1}$ for post soil samples. Mean M3K concentration did not change for Corn rice and Fallow treatments, whereas reduced for all other treatments (Figure 8). 

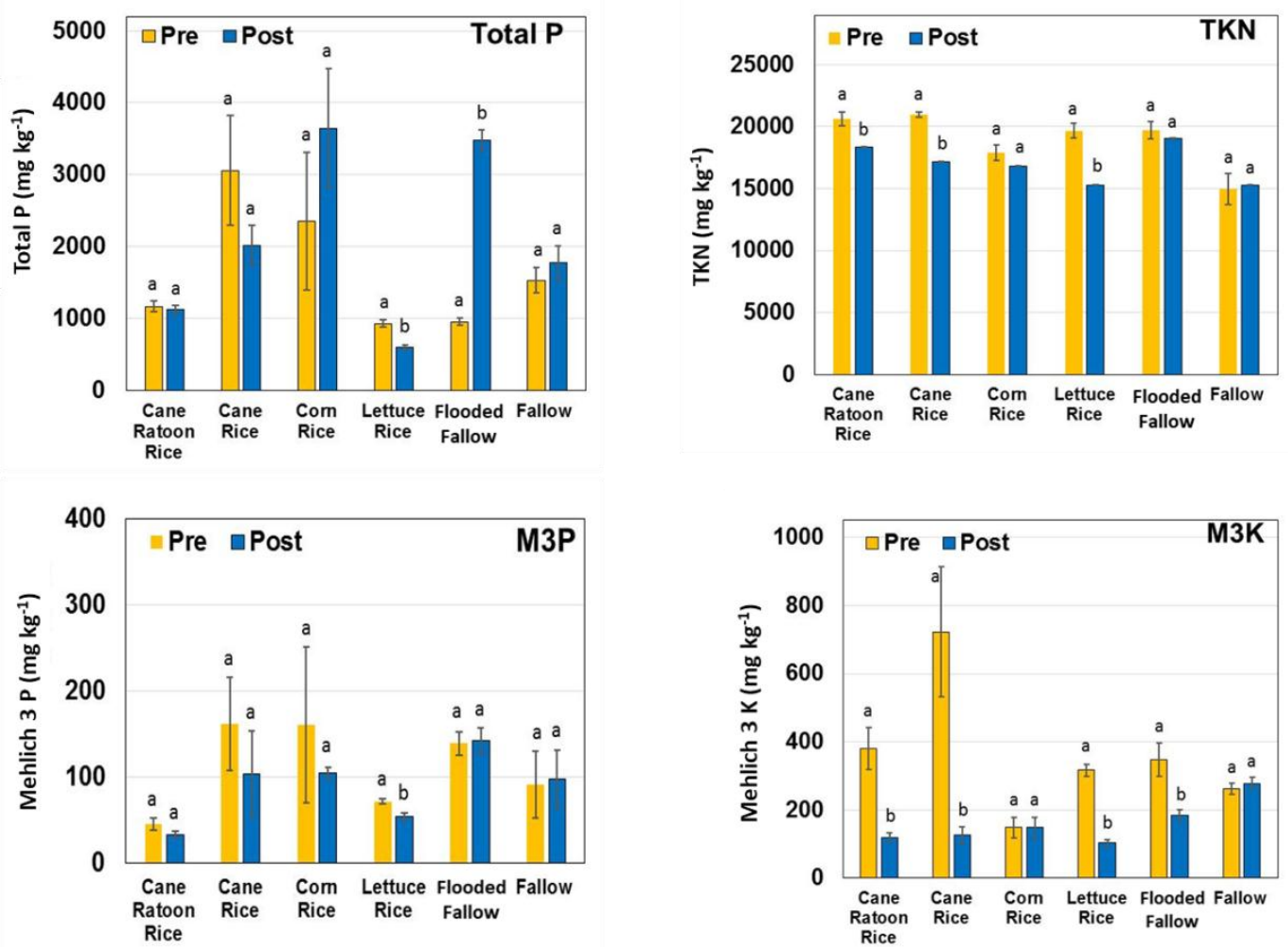

Figure 8. Changes in soil TP, TKN, Mehlich $3 \mathrm{P}$, and Mehlich $3 \mathrm{~K}$ concentrations pre and post six farming practice (mean and standard deviation). Different lower case alphabets correspond to significant differences $(\mathrm{p} \leq 0.05)$

Soil Health Index for various soil health parameters from different crop rotation practices are summarized in Table 2.

Table 2. Cumulative normal distribution values (a) and scores (b) for various soil health parameters for pre and post rice study

\begin{tabular}{|c|c|c|c|c|c|c|c|c|c|c|c|c|c|c|c|c|c|c|c|c|}
\hline \multicolumn{21}{|l|}{ a. $\mathrm{CND}^{\ddagger}$} \\
\hline & \multicolumn{2}{|l|}{$\mathrm{pH}$} & \multicolumn{2}{|l|}{$\mathrm{BD}^{\dagger}$} & \multicolumn{2}{|l|}{$\mathrm{OM}$} & \multicolumn{2}{|l|}{ MWHC } & \multicolumn{2}{|c|}{ Active C } & \multicolumn{2}{|l|}{ CEC } & \multicolumn{2}{|l|}{ M3P } & \multicolumn{2}{|l|}{ M3K } & \multicolumn{2}{|l|}{$\mathrm{TP}$} & \multicolumn{2}{|l|}{ TKN } \\
\hline & Pre & Post & Pre & Post & Pre & Post & Pre & Post & Pre & Post & Pre & Post & Pre & Post & Pre & Post & Pre & Post & Pre & Post \\
\hline Cane Ratoon & 0.18 & 0.29 & 0.29 & 0.24 & 0.69 & 0.77 & 0.41 & 0.95 & 0.66 & 0.84 & 0.22 & 0.84 & 0.33 & 0.30 & 0.69 & 0.25 & 0.30 & 0.29 & 0.78 & 0.48 \\
\hline \multicolumn{21}{|l|}{ Rice } \\
\hline Cane Rice & 0.23 & 0.69 & 0.61 & 0.20 & 0.52 & 0.61 & 0.46 & 0.86 & 0.60 & 0.83 & 0.15 & 0.79 & 0.59 & 0.46 & 0.98 & 0.26 & 0.86 & 0.58 & 0.81 & 0.32 \\
\hline Corn Rice & 0.86 & 0.77 & 0.61 & 0.46 & 0.43 & 0.51 & 0.18 & 0.80 & 0.40 & 0.83 & 0.76 & 0.77 & 0.58 & 0.46 & 0.29 & 0.34 & 0.69 & 0.94 & 0.42 & 0.28 \\
\hline Lettuce Rice & 0.08 & 0.80 & 0.69 & 0.58 & 0.62 & 0.70 & 0.25 & 0.62 & 0.65 & 0.04 & 0.11 & 0.24 & 0.38 & 0.35 & 0.58 & 0.23 & 0.24 & 0.16 & 0.67 & 0.13 \\
\hline Flooded & 0.76 & 0.83 & 0.33 & 0.70 & 0.55 & 0.72 & 0.06 & 0.70 & 0.13 & 0.29 & 0.75 & 0.80 & 0.54 & 0.54 & 0.64 & 0.35 & 0.24 & 0.93 & 0.67 & 0.58 \\
\hline \multicolumn{21}{|l|}{ Fallow } \\
\hline Fallow & 0.23 & 0.54 & 0.45 & 0.85 & 0.08 & 0.06 & 0.33 & 0.33 & 0.17 & 0.82 & 0.38 & 0.43 & 0.43 & 0.44 & 0.49 & 0.51 & 0.42 & 0.50 & 0.11 & 0.13 \\
\hline \multicolumn{21}{|l|}{ b. SCORE } \\
\hline & \multicolumn{2}{|l|}{$\mathrm{pH}$} & \multicolumn{2}{|l|}{$\mathrm{BD}$} & \multicolumn{2}{|l|}{$\mathrm{OM}$} & \multicolumn{2}{|c|}{ MWHC } & \multicolumn{2}{|c|}{ Active C } & \multicolumn{2}{|l|}{ CEC } & \multicolumn{2}{|l|}{ M3P } & \multicolumn{2}{|l|}{ M3K } & \multicolumn{2}{|l|}{$\mathrm{TP}$} & \multicolumn{2}{|l|}{ TKN } \\
\hline & Pre & Post & Pre & Post & Pre & Post & Pre & Post & Pre & Post & Pre & Post & Pre & Post & Pre & Post & Pre & Post & Pre & Post \\
\hline Cane Ratoon & 82.36 & 70.84 & 70.60 & 76.41 & 68.91 & 76.61 & 41.35 & 94.70 & 34.22 & 16.20 & 22.07 & 83.52 & 32.72 & 30.26 & 68.84 & 25.20 & 30.13 & 28.81 & 78.11 & 48.47 \\
\hline \multicolumn{21}{|l|}{ Rice } \\
\hline Cane Rice & 76.61 & 30.72 & 39.00 & 79.94 & 51.83 & 61.00 & 45.79 & 85.69 & 39.66 & 16.87 & 15.07 & 78.57 & 58.67 & 45.51 & 97.78 & 26.15 & 86.23 & 58.21 & 81.46 & 32.17 \\
\hline Corn Rice & 13.90 & 22.70 & 39.30 & 54.37 & 42.58 & 50.65 & 18.13 & 79.58 & 59.95 & 17.01 & 75.93 & 77.06 & 58.46 & 45.83 & 29.44 & 34.37 & 68.91 & 94.42 & 42.32 & 28.33 \\
\hline Lettuce Rice & 91.90 & 19.88 & 30.60 & 42.20 & 62.05 & 69.99 & 25.16 & 62.19 & 34.75 & 96.06 & 10.59 & 24.47 & 38.33 & 34.52 & 58.17 & 22.89 & 23.59 & 15.89 & 66.59 & 13.17 \\
\hline Flooded & 24.12 & 16.96 & 66.60 & 29.71 & 54.84 & 72.44 & 6.30 & 69.71 & 86.71 & 71.33 & 74.71 & 79.88 & 53.63 & 54.33 & 63.58 & 35.21 & 24.16 & 92.65 & 66.93 & 58.47 \\
\hline \multicolumn{21}{|l|}{ Fallow } \\
\hline Fallow & 77.00 & 45.60 & 54.71 & 15.29 & 7.65 & 6.06 & 32.87 & 32.87 & 83.10 & 17.94 & 37.56 & 43.17 & 42.74 & 44.17 & 48.66 & 51.44 & 41.73 & 49.82 & 10.63 & 13.17 \\
\hline
\end{tabular}

$\ddagger \mathrm{CND}=$ cumulative normal distribution. Positive Score $=100 * \mathrm{CND}$; Negative Score $=100 *(1-\mathrm{CND}) . \dagger \mathrm{BD}=$ bulk density; OM= organic matter content; $\mathrm{MWHC}=$ maximum water holding capacity; Active $\mathrm{C}=$ active carbon; $\mathrm{CEC}=$ cation exchange capacity; $\mathrm{M} 3 \mathrm{P}=\mathrm{Mehlich} 3$ phosphorus; $\mathrm{M} 3 \mathrm{~K}=$ Mehlich 3 potassium; $\mathrm{TP}=$ total phosphorus; $\mathrm{TKN}=$ total Kjeldahl nitrogen 
Overall changes in SHI due to rice planting are summarized in Figure 9a. and Table 3a. There was overall increase in SHI for Cane ratoon rice, corn rice and flooded fallow treatments while there was net decrease in SHI for Cane rice, Lettuce rice and Fallow treatments. We also developed SHI for the treatments including all scores expect nutrients (M3P, M3K, TKN, TP) to see soil health change in other parameters excluding nutrients (Fig. 9b and Table 3b). There was net increase in SHI for all rice rotation practices along with flooded fallow treatment; whereas there was net decrease in SHI for fallow treatment only when excluding the nutrients.
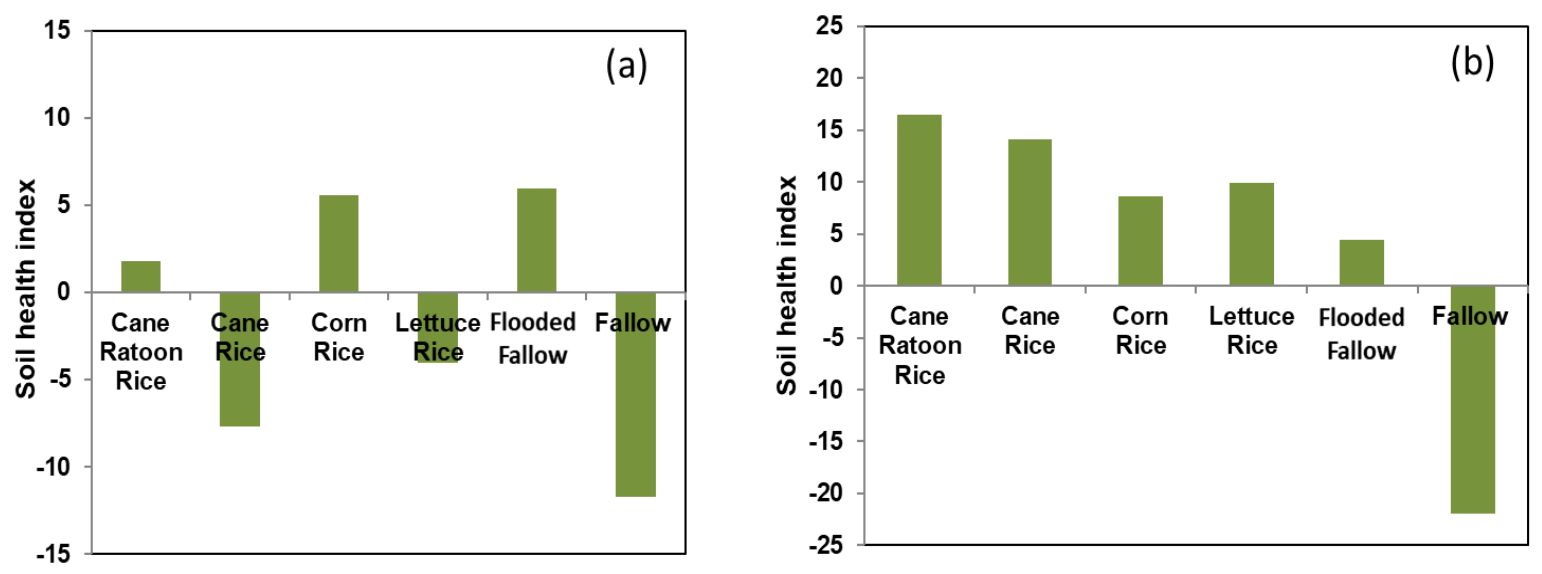

Figure 9. (a) Changes in overall soil health index for pre and post samples for various farming practices. (b) Changes in soil health index derived from indicators excluding nutrients (Mehlich-3P, Mehlich-3K, TKN, TP) for pre and post samples for various farming practices

Table 3. Changes in overall soil health index for pre and post samples for various farming practices including nutrients (a) and excluding nutrients (b)

\begin{tabular}{lccc}
\hline a. Overall Score & & & \\
& Pre & Post & Score change \\
\hline Cane Ratoon Rice & 50.97 & 52.74 & 1.77 \\
Cane Rice & 59.21 & 51.48 & -7.73 \\
Corn Rice & 44.89 & 50.43 & 5.54 \\
Lettuce Rice & 44.17 & 40.13 & -4.05 \\
Flooded Fallow & 52.16 & 58.07 & 5.91 \\
Fallow & 43.67 & 31.95 & -11.71 \\
\hline b. Score (w/o nutrients) & & & \\
& Pre & Post & Score change \\
\hline Cane Ratoon Rice & 53.25 & 69.72 & 16.46 \\
Cane Rice & 44.66 & 58.80 & 14.14 \\
Corn Rice & 41.63 & 50.23 & 8.59 \\
Lettuce Rice & 42.51 & 52.47 & 9.96 \\
Flooded Fallow & 52.21 & 56.67 & 4.46 \\
Fallow & 48.81 & 26.82 & -21.99 \\
\hline
\end{tabular}

\section{Discussion}

\subsection{Changes in Soil Health Indicators}

The high $\mathrm{pH}$ of the soils are a result of years of mixing of underlying limestone (calcium carbonate) bedrock with the top soil. As these soils get shallower, the mineral fraction comprising of $\mathrm{Ca}$ and $\mathrm{Mg}$-based minerals gets larger raising the soil $\mathrm{pH}$. The significant increase in soil $\mathrm{pH}$ post rice cultivation is probably due to the high $\mathrm{pH}$ (up to 9) observed in the irrigation water of local farm canals (Daroub et al., 2017). Increase in soil pH is a major concern for growers in the EAA as it can potentially lower the bioavailability of micro-nutrients from the soils (Sims \& Patrick, 1978). The slight decrease in bulk density observed between the pre and post soil samples of all rice cultivation farming practices may be due to the increase in OM content associated with the rice root density in the top soil. Once rice is harvested the roots and a few $\mathrm{cm}$ of the stalks remain in the soil, and gets tilled prior 
to planting of the subsequent crop. This lowering of soil BD is preferred because it facilitates aeration, better tilth, and limits root constriction. The significant increase observed in soil BD in the flooded fallow fields is due to compaction of the soil and lack of root density associated with rice cultivation. There was a significant increase in soil MWHC of soils that were flooded, this included all four treatments of rice cultivation and the flooded fallow fields. This increase in MWHC is probably related to the increase in the OM content of the soil. Bhadha et al. (2017) were able to demonstrate that by adopting farming methods that increase soil OM, growers can increase the MWHC of their soils. According to the USDA-NRCS, the most conservative estimates suggest that every $1 \%$ increase in soil OM will help soils hold up to 75,000 L more water per acre (Bryant, 2015). Cation exchange capacity significantly increased between the pre and post soils for the Cane ratoon rice and Cane rice framing practices. The CEC of soils is primarily controlled by the carbon content and clay sized particle fraction of soils (Parfitt et al., 1995). The histosols within the EAA inherently have very high carbon content (> 70\%), hence the CEC values are higher than $50 \mathrm{cmolc} \mathrm{kg}{ }^{-1}$. An increase in soil CEC between the pre and post soils is considered as a positive change because it can potentially retain non-foliar fertilizer and pesticides longer in the soil matrix. Pal and Vanjara (2001) were able to demonstrate that malathion (insecticide) and butachlor (herbicide) had greater affinity for soils composed of minerals like bentonite with higher CEC and higher surface area compared to kaolinite. Increasing soil OM is key to improving soil health (Doran \& Zeiss, 2000). Soils with high $\mathrm{OM}$ and aggregates can absorb and hold water during rainfall events and deliver it to plants during dry spells. Water is increasingly becoming the most limited natural resource supporting agriculture (Rijsberman, 2006), but growers in the EAA can improve their water storage capacity by raising their soil's OM content (Bhadha et al., 2017). Results indicate that flooded rice cultivation is a beneficial farming practice towards soil OM compared fallow fields. The amount of Active $\mathrm{C}$ content in a soil is a measure of the $\mathrm{C}$ that is susceptible to being mineralized to $\mathrm{CO}_{2}$ under ambient conditions over a short period of time. While Honeycutt (2017) showed that Active $\mathrm{C}$ was one of the three most important indicators of soil health that was positively correlated with crop yields; Roper et al. (2017) showed that Active C present in soils was increased with reduced tillage and often with organic amendments. Soil loss via oxidation is a concern in the EAA, hence an increase in Active C is not necessarily perceived as an ideal situation. However, while comparing flooded rice cultivation farming practices to fallow fields almost $16 \mathrm{~g} \mathrm{~kg}^{-1}$ of Active $\mathrm{C}$ is being generated during summer when the fields are left fallow, whereas no more than $8 \mathrm{~g} \mathrm{~kg}^{-1}$ of Active $\mathrm{C}$ is being generated under flooded practices. From a land management practice point of view, this is a great find because it demonstrates that cultivating flooded rice during summer in the EAA can lower the rate of carbon (soil) loss via oxidation.

Changes in $\mathrm{P}, \mathrm{N}$, and $\mathrm{K}$ in the soil was highly variable between the pre and post soil sampling. The reduction in M3P between the pre and post soil samples can be attributed to uptake by rice plant. Similarly, reduction in TKN can also be attributed to rice uptake. With no $\mathrm{N}$, P, or $\mathrm{K}$ added as fertilizer, rice cultivation in the EAA solely relies on the soils and irrigation water for its nutritional needs. While this may be beneficial from an environmental point of view, from a soil health perspective, rice cultivation does not seem to serve as a nutrient sink that can benefit the subsequent crop. Recent study conducted by Tootoonchi et al. (2018) indicated that flooded rice cultivation in the EAA can significantly lower $\mathrm{P}$ loading due to particulate settling and plant P-uptake during the growing season.

\subsection{Soil Health Index Used to Assess Farming Practice}

The SHI was developed taking into account all measured indicators, causing the scores generated from some indicators to mask others. This mostly occurs when the degree of variability of the indicator being measured is large, as was the case with nutrient concentrations. When SHI was estimated excluding nutrients, SHI increased for all treatments except fallow treatment. It was clear that soil nutrients had masked the effect of increase in soil health indices for other indicators. Crops require nutrients, and the decrease in nutrient concentration (M3P, $\mathrm{M} 3 \mathrm{~K}, \mathrm{TKN}, \mathrm{TP}$ ) following rice cultivation is natural and inevitable especially in this scenario since no N, P, K was added to the soils. Aside from nutrient uptake, there was net improvement in soil health due to rice planting. The depleted nutrients can always be replenished by adding fertilizers if needed. Even flooded fallow practice might me a sustainable agriculture practice rather than leaving the land completely fallow. Use of indices helps normalize the results and provides a board picture; however, it can also skew important information, so one should be careful while using results for interpretation without adequately disusing them.

\section{Conclusions}

Flooding the soils in general had a positive effect on soil health compared to fallow practices. Increase in soil pH within treatments between pre and post soil sampling was not considered as a positive response to soil health because these soils are high in calcium carbonate with $\mathrm{pH}$ ranging inherently upward of 7.2. The MWHC increased significantly under all "flooded" land practices compared to fallow fields; and from a soil health 
perspective this is advantageous, especially for water storage during dry spells. Significant increases in CEC observed in Cane ratoon rice, Cane rice, and Lettuce rice treatments suggests that the soils have a greater ability to retain insecticides and fertilizer within the topsoil. An increase in soil OM is extremely beneficial from a soil health perspective; however, its impact on histosols that are inherently composed of more than $60 \% \mathrm{OM}$ can only be perceived moderately. In terms of soil loss, left fallow, soils within the EAA generates up to $16 \mathrm{~g} \mathrm{~kg}^{-1} \mathrm{of}$ Active $\mathrm{C}$ that is highly susceptible to oxidation during the hot summer months in South Florida; compared to only about $8 \mathrm{~g} \mathrm{~kg}^{-1}$ if the soils are either flooded or planted with rice. Nutritionally, it was not surprising that soils contained lower $\mathrm{N}, \mathrm{P}$, and $\mathrm{K}$ concentrations after rice cultivation due to plant uptake and subsequent harvest. With no added N, P or K fertilizer the soils are the main source of labile (or extractable) nutrients to the rice plant. This was the premise for determining the SHI in two ways - (i) using all the measured indicators, and (ii) excluding soil nutrient indicators. It was evident from both approaches of SHI that leaving the fields fallow in the summer resulted in lower SHI values compared to flooded treatments. We hope that results from this study will encourage growers to plant more acreage of rice during the summer that will ultimately improve soil health and sustainability within the region.

\section{Acknowledgments}

This study was funded by the Florida Rice Growers Inc., and USDA National Institute of Food and Agriculture. Hatch Project FLA-ERC-005552.

\section{References}

Alkorta, I., Aizpurua, A., Riga, P., Albizu, I., Amezaga, I., \& Garbisu, C. (2003). Soil enzyme activities as biological indicators of soil health. Rev.Env. Health, 18, 65-73. https://doi.org/10.1515/REVEH.2003.18.1.65

Alvarez, J., Kidder, G., \& Snyder, G. H. (1979). Economic-potential for growing rice and sugarcane in rotation in the Everglades. Soil Crop Sci. Soc. Florida Proceedings, 38, 12-15. https://doi.org/10.2136/sssaj2004.1945

Andrews, S. S., Karlen, D. L., \& Cambardella, C. A. (2004). The soil management assessment framework: A quantitative soil quality evaluation method. Soil Sci. Soc. Am. J., 68, 1945-1962. https://doi.org/10.2136/sssaj2004.1945

Bhadha, J. H., Capasso, J. M., Khatiwada, R., Swanson, S., \& LaBorde, C. (2017). Raising soil organic matter content to improve water holding capacity, UF/IFAS Extension Publication\#SL 447.

Bhadha, J. H., \& Schroeder B. L. (2017). Best Management Practices for maintaining water quality in sugarcane cultivation., in: Rott, P. (Ed.), Achieving Sustainable Cultivation of Sugarcane Volume 1: Cultivation techniques, quality and sustainability. Burleigh Dodds Science Publishing, Cambridge, UK. https://doi.org/10.19103/AS.2017.0035.14

Bryant, L. (2015). Organic Matter Can Improve Your Soil's Water Holding Capacity.” NRDC Expert Blog, retrieved from https://www.nrdc.org/experts/lara-bryant/organic-matter-can-improve-your-soils-water-holding-capacity.

Cherry, R., Tootoonchi, M., Bhadha, J. H., Lang, T. A., Karounos, M., \& Daroub, S. (2015). Effect of Flood Depth on Rice Water Weevil (Coleoptera: Curculionidae) Populations in Florida Rice Fields. J. Ent. Sci., 50, 311-317. https://doi.org/10.18474/JES15-05.1

Daroub, S. H., Lang, T. A., Cooper, J., \& Sexton, A. (2017). Implementation and Verification of BMPs for Reducing P Loading from the Everglades Agricultural Area: Floating Aquatic Vegetation Impact on Farm Phosphorus Load, Annual Report. Submitted to the Everglades Agricultural Area Environmental Protection District and the South Florida Water Management District.

Doran, J. W., Coleman, D. C., Bezdicek, D. F., \& Stewart, B. A. (1994). Defining soil quality for a sustainable environment. SSSA Madison, WI.

Doran, J.W., \& Zeiss, M. R. (2000). Soil health and sustainability: managing the biotic component of soil quality. App. Soil Eco., 15, 3-11. https://doi.org/10.1016/S0929-1393(00)00067-6

Follett, R.F., Stewart, J. B., \& Cole, C. V. (1987). Soil Fertility and Organic Matter as Critical Components of Production Systems. SSSA Madison, WI.

FRG. (2017). Communications with Florida Rice Growers Inc.

Honeycutt , C. W. (2017). Implications of Soil Health and Food Security. SSSA Meeting, Tampa, FL. 
Jenkinson, D. S., \& Powlson, D. S. (1976). Effects of biocidal treatments on metabolism in soil .5. Method for measuring soil biomass. Soil Bio. Biochem., 8, 209-213. https://doi.org/10.1016/0038-0717(76)90005-5

Moebius-Clune, B. N., Moebius-Clune, D. J., Gugino, B. K., Idowu, O. J., Schindelbeck, R. R., Ristow, A. J., ... Abawi, G. S. (2016). Comprehensive Assessment of Soil Health - The Cornell Framework, 3.2 ed. Cornell University, Geneva, NY.

Pal, O. R., \& Vanjara, A. K. (2001). Removal of malathion and butachlor from aqueous solution by clays and organoclays. Separation and Purification Technology, 24, 167-172. https://doi.org/10.1016/S1383-5866(00)00226-4

Parfitt, R. L., Giltrap, D. J., \& Whitton, J. S. (1995). Contribution of organic-matter and clay-minerals to the cation-exchange capacity of soils. Comm. Soil Sci. Plant Anal., 26, 1343-1355. https://doi.org/10.1080/00103629509369376

Ponnamperuma, F. A. (1984). Effects of flooding on soils, in: T.T., Kozlowski (Eds.), Flooding and Plant Growth. Academic Press Inc., Orlando, FL. https://doi.org/10.1016/B978-0-12-424120-6.50007-9

Reddy, K. R., \& Patrick W. W. (1975). Effect of alternate aerobic and anaerobic conditions on redox potential, organic-matter decomposition and nitrogen loss in a flooded soil. Soil Bio. Biochem., 7, 87-94. https://doi.org/10.1016/0038-0717(75)90004-8

Rijsberman, F. R. (2006). Water scarcity: Fact or fiction?, Agricultural Water Management, 80(1-30), 5-22. https://doi.org/10.1016/j.agwat.2005.07.001

Roper, W. R., Osmond, D. L., Heitman, J. L., Wagger, M. G., \& Reberg-Horton, S. C. (2017). Soil health indicators do not differentiate among agronomic management systems in North Carolina soils. Soil Sci. Soc. Am. J., 81, 828-843. https://doi.org/10.2136/sssaj2016.12.0400

Schueneman, T., Rainbolt, C. \& Gilbert, R. (2008). Rice in the crop rotation. University of Florida IFAS EDIS Publication \# SS-AGR-23.

Sims, J. R., \& Patrick, W. H. (1978). The distribution of micronutrient cations in soil under conditions of varying redox potential and pH. Soil Sci. Soc. Am. J., 42, 258-262. https://doi.org/10.2136/sssaj1978.03615995004200020010x

Sumner, M. E., \& Miller M. P. (1996). Cation exchange capacity and exchange coefficient. . In Sparks (ed) Methods of soil analysis, part 3: Chemical Methods., Madison, Wisconsin., (pp. 1201-1230).

Tootoonchi, M., Bhadha, J. H., Lang, T. A., McCray, M. J, Clark, M. W., \& Daroub, S. H. (2018). Reducing drainage water phosphorus concentration with rice cultivation under different water management regimes. Agricultural Water Management, 205, 30-37. https://doi.org/10.1016/j.agwat.2018.04.036

Wright, A., \& Snyder, G. (2009). Soil Subsidence in the Everglades Agricultural Area. University of Florida IFAS EDIS Publication \# SL311.

\section{Copyrights}

Copyright for this article is retained by the author(s), with first publication rights granted to the journal.

This is an open-access article distributed under the terms and conditions of the Creative Commons Attribution license (http://creativecommons.org/licenses/by/3.0/). 